\title{
Seeming field allelopathic activity of Cynara cardunculus L. reduces the soil weed seed bank
}

\author{
Aurelio Scavo $^{1} \cdot$ Alessia Restuccia $^{1} \cdot$ Cristina Abbate $^{1}\left(\mathbb{D} \cdot\right.$ Giovanni Mauromicale $^{1}$ \\ Accepted: 17 May 2019 / Published online: 5 August 2019 \\ (C) INRA and Springer-Verlag France SAS, part of Springer Nature 2019
}

\begin{abstract}
Weeds are one of the most important pests in agroecosystems, causing considerable economic losses on the production. The widespread use of herbicides during the last decades has led to an increased search for more environmentally sustainable methods for weed management. The manipulation of allelopathic interactions between crops and weeds, such as the introduction of an allelopathic species within a crop rotation, represents a valid alternative. In a multidisciplinary approach, we evaluated the effects resulting from three consecutive years of cultivation, in two different areas, with the three botanical varieties of Cynara cardunculus L. (globe artichoke, cultivated and wild cardoon), compared with a classic Mediterranean wheat/faba bean rotation and an olive grove, on the quali/quantitative weed soil seed bank and the changes in the eubacterial communities. Furthermore, the in vitro antibacterial activity of aqueous, methanolic, and ethanolic leaf extracts of cultivated cardoon against three bacteria involved in the soil $\mathrm{N}$-cycle was investigated. In both areas, C. cardunculus caused a significant reduction (from -34 to $-50 \%$ ) on the amount of weed seeds in all treatments compared to controls; in some cases, a reduction of the number of weed species was observed. On one hand, the presence of cultivated cardoon had a negative influence towards Bacillus subtilis, while on the other, a positive one towards the beneficial soil bacteria Pseudomonas putida and Azospirillum brasilense. Moreover, methanolic and ethanolic leaf extracts from cultivated cardoon showed an inhibitory activity on $B$. lichenoformis, while there were no negative effects on Rhizobium leguminosarum and Sinorhizobium meliloti, two important bacteria involved in biological $\mathrm{N}_{2}$ fixation. These results confirmed, for the first time, the field allelopathic activity of $C$. cardunculus in monoculture and the possibility of introducing it within a crop rotation as an indirect method for a chemical-free weed seed bank control while respecting soil eubacterial communities.
\end{abstract}

Keywords Cynara cardunculus · Allelopathy $\cdot$ Seed bank - Weed control · Crop rotation · Sustainability · Eubacterial communities

\section{Introduction}

In modern agriculture, due to the environmental impact of synthetic herbicides and the increasing incidence of resistance

Cristina Abbate

cristina.abbate@unict.it

Aurelio Scavo

aurelio.scavo@unict.it

Alessia Restuccia

a.restuccia@unict.it

Giovanni Mauromicale

g.mauromicale@unict.it

1 Department of Agriculture, Food and Environment (Di3A), University of Catania, via Valdisavoia, 5, 95123 Catania, Italy in weeds, the search for eco-friendly strategies for weed control has become of central importance. The manipulation of the cultivated plant allelopathic mechanisms via crop rotation could represent the first step to reduce the soil seed bank in the agroecosystems, making it possible to control weeds with low environmental impact (Scavo et al. 2018a).

The soil seed bank refers to the reserve of all viable (dormant as well as ready to germinate) weed seeds stored in the soil in a given area. In agroecosystems, it is the primary source of new infestations of annual weeds and represents the majority of the weed species composition (Cavers 1983). Soil seed bank characteristics play a fundamental role both on the weed populations occurring in a field and the subsequent weed management. Since the real weed flora almost exclusively derives from the potential weed population communities, knowing the seed bank size, composition, vertical distribution, and dynamic plays a key role in weed management. Thus, reducing the 
number of the weed seeds present in the soil seed bank is an important goal in the Integrated Weed Management System (IWMS). In this way, preventive methods such as crop rotation are of key importance; indeed, it is considered the most important example for such allelopathic weed control (Farooq et al. 2011). Several crops such as sugar beet (Kalburtji and Gagianas 1997), sunflower (Alsaadawi et al. 2012), etc. have been reported to exert allelopathic effects on weeds when introduced within a crop rotation. Moreover, crop rotation is associated with many benefits since it can reduce pest (both pathogens and weeds) pressure and soil erosion, improve the amount of soil organic matter and soil physical properties, reduce nutrient leaching, enhance soil fertility and, thus, increase yields (Snapp et al. 2005).

Recently, the Asteraceae member Cynara cardunculus L. was studied for its allelopathic potential (Scavo et al. 2018b, 2019a). The compounds responsible for this phytotoxic activity are sesquiterpene lactones such as cynaropicrin, aguerin B and grosheimin, and polyphenols such as chlorogenic acid, luteolin- and apigenin derivatives (Pandino et al. 2012). However, its allelopathic effects in field conditions have never been evaluated. C. cardunculus is an ancient complex $\mathrm{C}_{3}$ species within the Asteraceae family, native to the Mediterranean Basin, and includes three taxa: the two domesticated forms, globe artichoke [var. scolymus (L.) Fiori] and cultivated cardoon (var. altilis DC.), along with their common progenitor wild cardoon [var. sylvestris (Lamk) Fiori]. The globe artichoke is cultivated primarily for its immature inflorescence, which is consumed both fresh and processed (Portis et al. 2005). Nowadays, it is widely distributed throughout the world, especially in Southern Europe, Middle East, Northern Africa, Southern America, USA, and recently also in China. The cultivated cardoon, on the contrary, is not very widespread, remaining of regional importance in Spain, Italy, Greece, and the south of France, where the commercial product is the enlarged bleached petiole of the leaves. In recent years, the species $C$. cardunculus has been considered for a multitude of industrial applications (Pesce et al. 2017).

Several preliminary supports on the influence of soil microbial community on plant species abundance, seedling recruitment, and seed bank dynamics have been provided, although other investigations are required (Singh et al. 2004; Chee-Sanford et al. 2006). Since seed bank and soil microorganisms are affected by the same soil physical, chemical, and biological characteristics (e.g., soil texture, structure, $\mathrm{pH}, \mathrm{O}_{2}$ and $\mathrm{CO}_{2}$ content, etc.), it is reasonable to assert that changes in the seed bank are correlated to changes in the microbial community (Chee-Sanford et al. 2006). The antimicrobial activity of C. cardunculus leaf extracts is well documented in literature (Kukić et al. 2008; El Sohaimy 2014). Caffeoylquinic acids and flavonoids are the chemical compounds involved in its antimicrobial activity (Scavo et al. 2019b). However, C. cardunculus inhibitory effects have never been evaluated on Rhizobium leguminosarum, Sinorhizobium meliloti, and Bacillus licheniformis, which are three important bacteria involved in the soil N-cycle. $R$. leguminosarum is a well-known plant growth-promoting rhizobacterium (PGPR), which includes three biovars corresponding to the plants involved in the symbiosis: R. leguminosarum biovar viciae, $R$. leguminosarum biovar trifolii, and R. leguminosarum biovar phaseoli. S. meliloti is a Gram-negative bacterium that nodulates the roots of alfalfa (Medicago sativa L.). Both bacteria play a key agronomic role in the survival of leguminous plants growing in extreme conditions (e.g., arid regions), since the biological $\mathrm{N}_{2}$ fixation (BNF) can achieve values of 200 $300 \mathrm{~kg} \mathrm{~N} \mathrm{ha}^{-1}$ per year for various legume crops and pasture species (Peoples et al. 1995). Kim et al. (2005) reported that the Bacillus strains were able to simultaneously occur in aerobic nitrification/denitrification. B. licheniformis was found to convert ammonia to $\mathrm{N}_{2}$ without the formation of nitrous oxide under aerobic conditions. Therefore, in this process, the heterotrophic Bacillus strains present less complex metabolic pathways than autotrophs.

Our hypothesis is that allelochemicals from globe artichoke, cultivated and wild cardoon, which show phytotoxic and antimicrobial activity in vitro bioassays, could decrease weed seed bank after the repeated cultivation for several years in the same field through their direct action and/or microbial transformation (Fig. 1). Under a multidisciplinary research (agronomy, botany, soil microbiology), in this work, we studied for the first time (i) the effects resulting from the repeated cultivation in two different areas with globe artichoke, cultivated and wild cardoon, compared with a classic rotation of wheat/faba bean and an olive grove, on the quali/quantitative composition of soil seed bank, (ii) the related changes in the eubacterial communities, and (iii) the in vitro antibacterial activity of aqueous, methanolic, and ethanolic leaf extracts of cultivated cardoon against $R$. leguminosarum, S. meliloti, and $B$. licheniformis.

\section{Material and methods}

\subsection{Soil seed bank}

\subsubsection{Studied area and experimental design}

The investigation on the weed seed bank was carried out exploiting two different field experiments: experiment 1 was set up at the Agricultural Experimental Farm (AEF) of Catania University (Catania Plain, $37^{\circ} 25^{\mathrm{I}} \mathrm{N}, 15^{\circ} 30^{\mathrm{I}} \mathrm{E} ; 10 \mathrm{~m}$ a.s.1.); experiment 2 in Passitti (Catania Plain, $37^{\circ} 26^{\mathrm{I}} \mathrm{N}, 14^{\circ} 56^{\mathrm{I}} \mathrm{E}$; $20 \mathrm{~m}$ a.s.1.). In both areas, the climate is semiaridMediterranean, with a long, hot and dry summer, mild winter and rain falling mostly from late autumn to early spring. Daily mean temperature during the year ranges from 8.5 to $26{ }^{\circ} \mathrm{C}$ : 

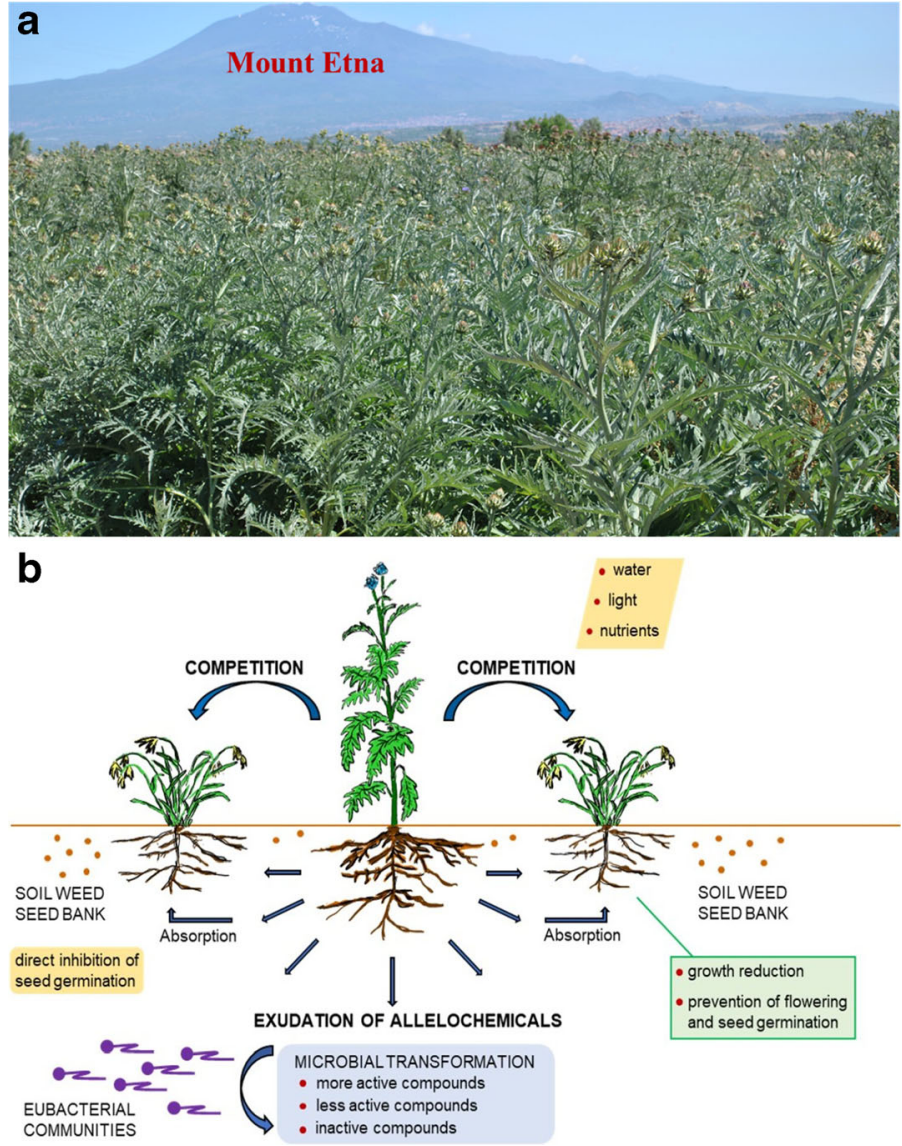

Fig. 1 Sustainability of Cynara cardunculus L. in agroecosystems: a view of cultivated cardoon in the Catania Plain (Italy, Sicily). b C. cardunculus competes with weeds for water, light, and nutrients. On the other side, it releases allelochemicals into the soil system, primarily by root exudation. Allelochemicals affect the soil weed seed bank both

minimum temperature is around $0{ }^{\circ} \mathrm{C}$, while maximum can peak at over $35^{\circ} \mathrm{C}$. Annual precipitation is about $500 \mathrm{~mm}$. On the basis of Rivas-Martinez bioclimatic indexes, the sampling areas may be classified within the thermoMediterranean upper bioclimatic belt, with inferior dry ombrotype. The soils of the Catania Plain are alluvial, with medium fine-coarse texture (soils from clayey-loamy to sandy-loamy, from sandy to loamy-sandy and andic xerochrepts). The soil type at the AEF is vertic xerochrepts with clay texture. At the start of the experiment, the soil characteristics were as follows: sand (18\%), silt (36\%), clay (46\%), limestone (4\%), $\mathrm{pH}(8)$, organic matter $(1.1 \%)$, total nitrogen $\left(1.1 \mathrm{mg} \mathrm{kg}^{-1}\right)$, assimilable $\mathrm{P}_{2} \mathrm{O}_{5}\left(12 \mathrm{mg} \mathrm{kg}^{-1}\right)$, exchangeable $\mathrm{K}_{2} \mathrm{O}\left(425 \mathrm{mg} \mathrm{kg}^{-1}\right)$, electrical conductivity $\left(0.4 \mathrm{dSm}^{-1}\right)$. At Passitti, the soil is classified as a tipic xero-fluvent with a clay loam texture: sand $(40 \%)$, silt $(25 \%)$, clay $(35 \%)$, limestone $(2 \%), \mathrm{pH}(7.9)$, organic matter (1.6\%), total nitrogen $\left(1.3 \mathrm{~g} \mathrm{~kg}^{-1}\right)$, assimilable $\mathrm{P}_{2} \mathrm{O}_{5}$ $\left(50 \mathrm{mg} \mathrm{kg}^{-1}\right)$, exchangeable $\mathrm{K}_{2} \mathrm{O}\left(425 \mathrm{mg} \mathrm{kg}^{-1}\right)$, electrical conductivity $\left(0.41 \mathrm{dSm}^{-1}\right)$. Each field experiment was set out in a randomized block design with four replicates per directly and indirectly: the former through the inhibition of seed germination, the latter by reducing the growth and preventing flowering of weeds. Nevertheless, C. cardunculus allelochemicals affect the soil eubacterial communities and, vice versa, are transformed by soil microorganisms into more active, less active or inactive compounds

treatment, based on a net plot size of $20 \times 20 \mathrm{~m}$ per replication. Experiment 1 consisted of (i) a monoculture for three consecutive years (from 2014 to 2017) with globe artichoke; (ii) a monoculture of cultivated cardoon for three consecutive years; (iii) a classic rotation of faba bean (Vicia faba L.) and wheat (Triticum durum Desf.) for 4 years as control. The choice of this control is owed of the fact that the grain legume/cereal rotation is the most common in the hot-arid zones of the Mediterranean Basin. The globe artichoke and cardoon plots were planted in August by "ovoli" (semidormant offshoots) or seeds (achenes), respectively, using an inter- and intra-row spacing of 1.25 and $0.70 \mathrm{~m}$. In the second and third year, the regrowth after the period of summer dormancy was carried out in August by irrigation. Seeds of faba bean and wheat were sown in November using a density of 40 and 400 seeds $\mathrm{m}^{-2}$, respectively. Experiment 2 was carried out in (i) a monoculture for three consecutive years (from 2014 to 2017) with cultivated cardoon; (ii) a monoculture of wild cardoon for three consecutive years; (iii) an olive grove at the fourth year, a typical crop of the Mediterranean. In both experiments, globe artichoke and 
cardoons were grown in monoculture because they are typically cultivated as polyannual crops on the same field in the Mediterranean environment. Since the three botanical varieties of $C$. cardunculus were cultivated in a 3-year monoculture, they were compared, in addition to a classic wheat/faba bean rotation, also with a perennial crop like the olive grove. Cardoon plots were planted and managed in the same way as those of experiment 1 . The olive trees, 3 years old, were planted with a spacing of $4 \mathrm{~m}$ within rows $\times 6 \mathrm{~m}$ between rows (417 plants ha ${ }^{-1}$ ). For all crops, the standard commercial practices were adopted. Weeds were mechanically controlled, for each season and rotation, by shallow hoeing $(0.15 \mathrm{~m}$ deep) twice (end of September and early February) a year, without incorporation of plant material. At these times, most of weeds were at the young development stage between the 3-4th and 7-8th expanded leaves.

\subsubsection{Soil seed bank sampling and seed identification}

Since the utilization of a biennial rotation as control for the experiment 1 , in AEF, the soil samples were collected twice (May 2015 and 2017) to obtain an intermediary evaluation of the soil seed bank. In experiment 2 , on the contrary, as the control was a perennial crop, the collection of soil samples was carried out at the end of the third year (May 2017). At these sampling dates, all the winter-spring plant species were intercepted along the diagonals of each plot. Ten soil cores per plot (each of $0.75 \mathrm{dm}^{3}$ ) were collected with a metallic probe up to $15 \mathrm{~cm}$ depth. Soil samples were stored in paper bags for a few days at $4{ }^{\circ} \mathrm{C}$ in the dark before being analyzed to prevent seed germination prior to identification. Each soil sample was carefully mixed in the laboratory and the inert fraction (stones, pebbles, etc.) was hand-removed, because it would render their washing difficult. For the direct seed extraction, seeds were separated from soil by washing. For an adequate representation of the entire soil core, four subsamples of $150 \mathrm{~g}$ for each plot were put into a metal tube with a removable cap fitted with steel mesh of $250 \mu \mathrm{m}$ and were washed through an electric adjustable pressure (20-120 bar max) washer (Karcher, K 3500 model, Germany). Before seed extraction, soil samples from each core were pre-treated and mixed with $5 \mathrm{~g}$ of sodium hexametaphosphate solution for $20 \mathrm{~min}$, to disperse the colloid matrix and facilitate the subsequent washing stages. The extracted fraction, composed of seeds mixed with mineral and organic particles, was transferred into Petri dishes and was air-died for $24 \mathrm{~h}$ for the hand separation; seeds were isolated from the remaining matter, then identified and counted. All the observations were performed using a MS5 Leica stereomicroscope (LeicaMicrosystems, Wetzlar, Germany). For the assessment of viability, the extracted seeds were submitted to the tetrazolium test. The values of viable seeds in each subsample were expressed as the number of seeds $\mathrm{m}^{-2}$ of surface area for each plot. Seeds were grouped in relation to botanical family and each species was assigned to a life-form category considering the Raunkiaer system.

\subsection{Soil molecular analyses}

\subsubsection{DNA extraction}

DNA was directly extracted from $250 \mu \mathrm{L}$ of soil samples (Martin-Laurent et al. 2001). Samples were homogenized in $1 \mathrm{~mL}$ of extraction buffer [100 mM Tris, $\mathrm{pH} 8 ; 100 \mathrm{mM}$ EDTA; $100 \mathrm{mM} \mathrm{NaCl} ; 1 \%(w / v)$ polyvinylpyrrolidone; $2 \%$ $(w / v)$ sodium dodecyl sulfate] for $30 \mathrm{~s}$ at $1600 \mathrm{rpm}$ in a minibead cell disrupter. Cell debris was removed by centrifugation (5 min at $14,000 \mathrm{~g}$ ). Proteins were eliminated after sodium acetate precipitation. Nucleic acids were precipitated with cold isopropanol, then washed with $70 \%$ ethanol. DNA extracts were purified with a polyvinylpyrrolidone spin column. The quality and the integrity of the DNA were checked by electrophoresis on $1 \%$ agarose gel.

\subsubsection{Amplification of eubacterial $16 \mathrm{~S}$ rDNA fragments}

In order to verify the effects resulting from the repeated cultivation for three consecutive years with globe artichoke and cultivated cardoon, compared with a classic wheat/faba bean rotation (experiment 1) on soil eubacterial communities, the molecular analysis was performed by PCR amplification of $16 \mathrm{~S}$ rDNA genes from the total DNA of each sample and separation on parallel denaturing gradient gel by electrophoresis.

Eubacterial 16S rDNA was amplified using the primer sets GC-968f (5'-CGC CCG GGG CGC GCC CCG GGC GGG GCG GGG GCA CGG GGG GAA CGC GAA GAA CCT TA-3') and 1401r (5'-GCG TGT GTA CAA GAC CC-3'), as described by Felske et al. (1997) to obtain products of about $450 \mathrm{bp}$. The DNA template $(80 \mathrm{ng}$ ) was amplified with 5 units $\mu \mathrm{L}^{-1}$ Taq DNA Polymerase, $10 \mu \mathrm{M}$ of each primer, $10 \mathrm{mM}$ of each dNTP, $10 \mathrm{mM}$ of $\mathrm{MgCl}_{2}, 500 \mu \mathrm{g} \mathrm{mL}^{-1}$ of BSA and reaction buffer $1 \times$ (Invitrogen) in a final reaction volume of $50 \mu \mathrm{L}$. The PCR conditions were $94^{\circ} \mathrm{C}$ for $90 \mathrm{~s}$, followed by 33 cycles at $95^{\circ} \mathrm{C}$ for $20 \mathrm{~s}, 56^{\circ} \mathrm{C}$ for $30 \mathrm{~s}, 72^{\circ} \mathrm{C}$ for $45 \mathrm{~s}$, and a final extension step at $72{ }^{\circ} \mathrm{C}$ for $7 \mathrm{~min}$. Amplicons were analyzed as described above.

\subsubsection{Denaturing gradient gel electrophoresis}

16S rDNA-DGGE was performed using the DCode System (Universal Mutation Detection System, BIO-RAD). An amount of $300 \mathrm{ng}$ of amplicons was loaded in triplicate (top filling method) on $6 \%$ polyacrylamide gel (Acrylamide/ Bisacrylamide, 40\%, 37.5:1, BIO-RAD) containing a denaturant gradient of $46-56 \%$ parallel to the electrophoresis direction made of urea and formamide (100\% denaturant contains 
$7 \mathrm{M}$ urea and $40 \%$ formamide). Gels were electrophoresed at a constant temperature $\left(60{ }^{\circ} \mathrm{C}\right)$ and voltage $(75 \mathrm{~V})$ for $16 \mathrm{~h}$, followed by $2 \mathrm{~h}$ coloration using SYBR Green I nucleic acid gel stain 1:1000 diluted in the running buffer (FMC Bio Products, Rockland, ME USA). Bands were detected from digital images (Polaroid Gel Cam, Elect; Polaroid Type 667 Film ISO 3000) by UV light gel transillumination ( $\lambda 312 \mathrm{~nm}$ ).

Bands to be sequenced were excised from the DGGE gels, placed in $50 \mu \mathrm{L}$ sterile $\mathrm{H}_{2} \mathrm{O}$, and stored at $-80{ }^{\circ} \mathrm{C}$. Before PCR amplification, the samples were thawed for $1 \mathrm{~h}$ at room temperature, frozen again at $-80{ }^{\circ} \mathrm{C}$ for $1 \mathrm{~h}$, and finally thawed at $4{ }^{\circ} \mathrm{C}$ overnight to elute the DNA fragments. The eluted DNA $(2 \mu \mathrm{L})$ was used as a template in PCR amplification with the primer set $968 \mathrm{f}-1401 \mathrm{r}$ (without the GC-clamp).

\subsection{In vitro antibacterial activity of leaf extracts}

\subsubsection{Sampling of plant material and preparation of leaf extracts}

Leaves of cultivated cardoon cv. Altilis 41, which was selected in a breeding program of the University of Catania on $C$. cardunculus, were collected randomly from 60 plants at the 25 th visible leaves growth stage in the AEF of Catania University. Thirty-five grams of dried leaves were macerated with $350 \mathrm{~mL}$ of bidistilled water (WE), a mixture methanol/bidistilled water 70:30 v/v (ME), and ethanol/bidistilled water 80:20 v/v (EE) for $72 \mathrm{~h}$ at $25{ }^{\circ} \mathrm{C}$ in the dark, and then filtered through filter paper (Whatman No.2) to eliminate the solid fraction. Methanolic and ethanolic mixtures were evaporated at $35{ }^{\circ} \mathrm{C}$ using a rotary evaporator (Laborata 4000, Heidolph, Germany) and the residues were re-dissolved with bidistilled water. The antibacterial bioassay was performed with three concentrations (100, 80, and 40\%) for each extract diluted with bidistilled water. The prepared extracts were transferred into a falcon flask and stored at $-20{ }^{\circ} \mathrm{C}$ for further uses.

\subsubsection{Determination of the antibacterial activity}

The antibacterial activity of cultivated cardoon leaf extracts was evaluated in vitro for the first time against the bacteria Rhizobium leguminosarum, Sinorhizobium meliloti, and Bacillus licheniformis, selected within the microbial collection of Di3A (University of Catania), by using the agar well diffusion method (Pagliaruolo et al. 2016). One milliliter of a 24-h culture of the target bacterial suspensions $\left(10^{8}\right.$ cells $\left./ \mathrm{mL}\right)$ was poured into sterile Petri dishes. Then, $20 \mathrm{~mL}$ of sterilized melted medium $\left(\sim 45^{\circ} \mathrm{C}\right)$, such as Tryptone yeast extract agar for $R$. leguminosarum and S. meliloti and Nutrient agar for $B$. licheniformis, was added into the dishes and mixed until the media was solidified; holes of $6.3 \mathrm{~mm}$ diameter were aseptically pierced by means of a sterile cork borer into the solidified media. One hundred microliters of tested extracts was introduced into the wells at the following concentrations, expressed as mg total measured polyphenols (sum of single polyphenol compounds) $\mathrm{mL}^{-1}$ of extract (Scavo et al. 2019b): $0.3336,0.278$, and 0.139 for $\mathrm{W} ; 1.7676,1.473$, and 0.7365 for ME; $1.2684,1.057$, and 0.5285 for EE. Since all the different dried extracts were re-dissolved in water before antibacterial assays, sterile bidistilled water was used as negative control. Plates were incubated at $28{ }^{\circ} \mathrm{C}$, until visible growth of test microorganisms in the control plates. The diameter of the inhibition zones, including well diameter (expressed in $\mathrm{mm}$ ), produced by the extracts against targeted bacterial species, was measured to quantify the antibacterial activity. The trial was repeated three times.

\subsection{Data and statistical analysis}

Bartlett's test was used to test homoscedasticity, and then, data were subjected to analysis of variance (ANOVA). Means were separated with the Student-Neuman-Keuls test only when the $F$ test of the ANOVA for treatments and interaction was significant at the 0.05 probability level.

As concerns the amount of weed seeds in the soil seed bank, a factorial two-way ANOVA model was used for experiment 1 to analyze the data, with cropping system and year as main factors. In addition, the differences in weed communities among cropping systems and year were estimated by using Sørensen's Similarity Indices (Magurran 2004).

- The qualitative index was calculated using the equation:

$$
\left[2 \mathrm{C} *(\mathrm{~A}+\mathrm{B})^{-1}\right]
$$

where $\mathrm{C}$ is the number of species in common, $\mathrm{A}$ is the total number of species in one of the two situations compared and $\mathrm{B}$ is the total number of species in the other situation

- The quantitative Sørensen index, also known as BrayCurtis similarity or Percentage similarity, was calculated as follows:

$$
\left[2 \mathrm{~N}_{\mathrm{t}} *\left(\mathrm{~N}_{\mathrm{a}}+\mathrm{N}_{\mathrm{b}}\right)^{-1}\right]
$$

where $\mathrm{N}_{\mathrm{t}}$ is the sum of the lowest density values of the species common to the two situations compared, $\mathrm{N}_{\mathrm{a}}$ is the sum of the density values of all species in one situation and $\mathrm{N}_{\mathrm{b}}$ is the sum of the density values of all species in the other situation. Sørenson's Similarity Indices range from 0 to 1 with high values indicating marked similarity between the situations compared. 

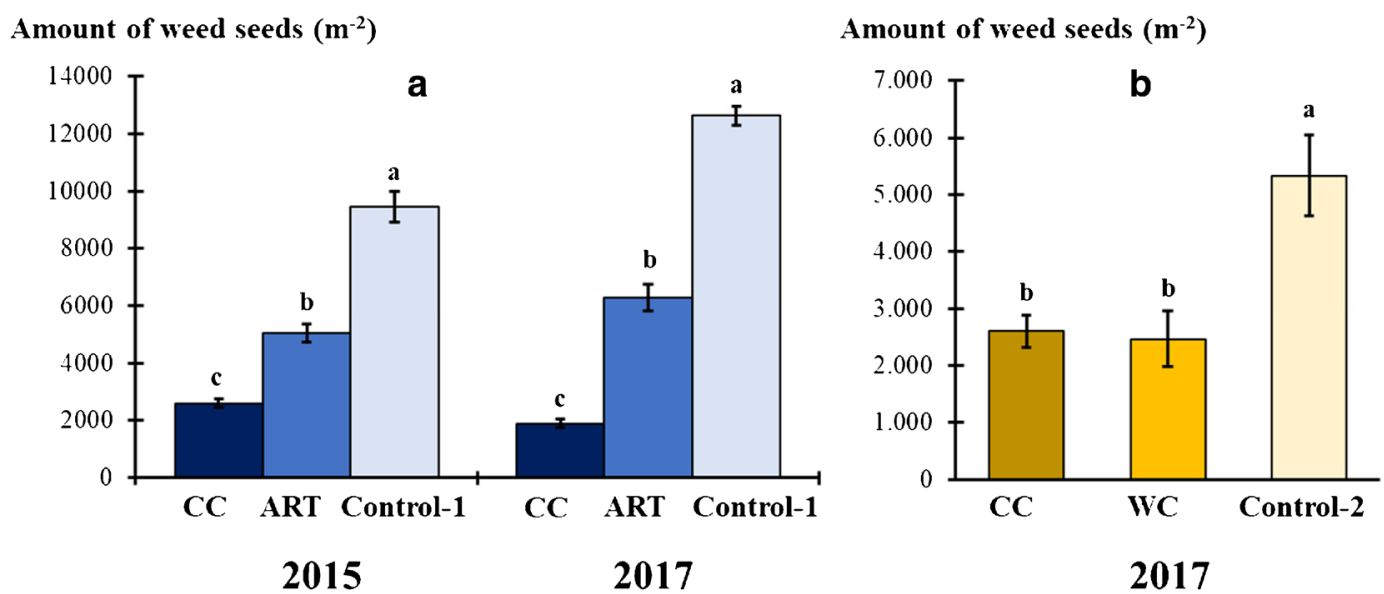

Fig. 2 Amounts of weed seeds in the soil seed bank in experiment 1 (a) and experiment 2 (b). CC: cultivated cardoon; ART: globe artichoke; WC: wild cardoon; Control-1: wheat/faba bean rotation; Control-2:

olive grove. Each bar means \pm standard error. Different letters indicate statistical significance for $p \leq 0.05$

\section{Results and discussion}

\subsection{Soil seed bank size and composition}

In agricultural soils, seed bank size values ranging from near 0 to as much 1 million seeds $\mathrm{m}^{-2}$ have been reported (Fenner 2012). Hossain and Begum (2015) also indicated that the introduction of perennial crops in annual cropping systems contributes to decrease the soil seed bank of annual species over time. In this study, the effect of $C$. cardunculus monoculture (for three consecutive years) in two different areas was evaluated on the size and composition of the soil weed seed bank, compared to a classical rotation in experiment 1 and a common perennial crop in experiment 2 , with the aim of assessing the potential inclusion of this species within a crop rotation as an indirect method for weed control.

Regarding the experiment 1, in 2015, the soil seed bank amounting to 9450 seeds $\mathrm{m}^{-2}$ in the control was almost halved to 5050 seeds $\mathrm{m}^{-2}$ due to the repeated cultivation of globe artichoke, and even more reduced to 2600 seeds $\mathrm{m}^{-2}$ in the plot with cultivated cardoon (Fig. 2). The same situation was found also in 2017, with even greater differences: the amount of weed seeds in the control $\left(12,650 \mathrm{~m}^{-2}\right)$, compared to those of globe artichoke and cultivated cardoon, was 2.0 and 6.6 times higher, respectively. The effect of the year on the analysis of variance was highly significant $(F=18 ; p<0.001)$. In fact, on the average of the three cropping systems for each year, the number of seeds in $2015\left(6950 \mathrm{~m}^{-2}\right)$ decreased to $5700 \mathrm{~m}^{-2}$ in 2017. Therefore, the effect of globe artichoke and cultivated cardoon monoculture on the soil seed bank increased if repeated for 3 years, probably due to the accumulation of allelochemicals released into the soil and to the competitive effects on emerged weeds. The cropping system was also highly significant $(F=318 ; p<0.001)$. In particular, on the average of the year of the experiment, the soil seed bank size of the control $\left(11,050 \mathrm{~m}^{-2}\right)$ significantly decreased to $5676 \mathrm{~m}^{-2}$ and $2250 \mathrm{~m}^{-2}$ in the plot cultivated with globe artichoke and cardoon, respectively. These results demonstrated, for the first time, both the greater competitive capacity and allelopathic activity of cardoons than globe artichoke in field conditions, probably due to the major content in cardoons of sesquiterpene lactones, as reported in an our unpublished study. Moreover, the size of the soil seed bank was affected by the "cropping system $\mathrm{x}$ year" interaction $(F=15$; $p<0.001)$ and the former contributed much more than the latter to the analysis of variance. Concerning experiment 2 , the seed bank of control (olive grove) which amounted to 5333 seeds $\mathrm{m}^{-2}$ was halved to 2600 and 2467 seeds $\mathrm{m}^{-2}$ due to the repeated cultivation of wild cardoon and cultivated cardoon, respectively (Fig. 2). Therefore, a reduction of the soil seed bank size was found in two different areas due to the repeated cultivation for three consecutive years of C. cardunculus, mainly the cardoons.

Regarding soil seed bank composition, a total of 25 weed species were identified in the $0-15-\mathrm{cm}$ soil layer in experiment 1 (Table 1). The seed bank was almost exclusively composed of herbaceous species, except for Platanus orientalis L. The analysis of the biological forms has pointed out a high percentage of therophytes (60\%) and hemicryptophytes (24\%), while geophytes $(12 \%)$ and phanerophytes $(4 \%)$ were poorly represented. Moreover, $60 \%$ of total weeds found were annual, $12 \%$ biennial and $28 \%$ perennial, belonging to 18 botanical families. The most representative families were Asteraceae (22\%), Brassicaceae (17\%), and Polygonaceae (11\%). Sinapis arvensis L. was the most abundant species in the soil seed bank both in 2015 (9400 seeds $\mathrm{m}^{-2}$ ) and $2017(15,000$ seeds $\mathrm{m}^{-2}$ ), followed by Anagallis arvensis L. (4600 seeds $\mathrm{m}^{-2}$ ) and Beta vulgaris L. (1467 seeds $\mathrm{m}^{-2}$ ) in 2015, and 


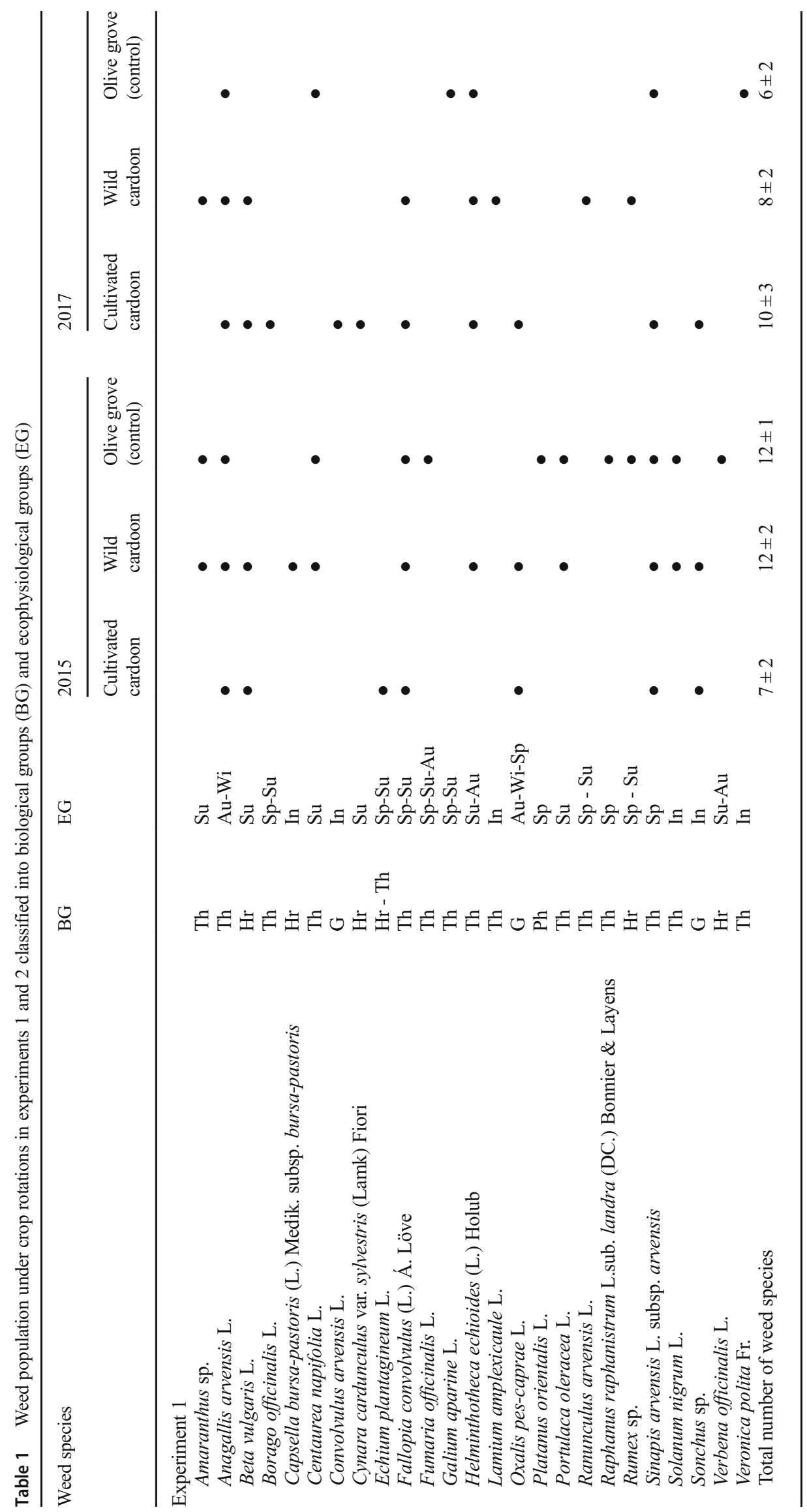




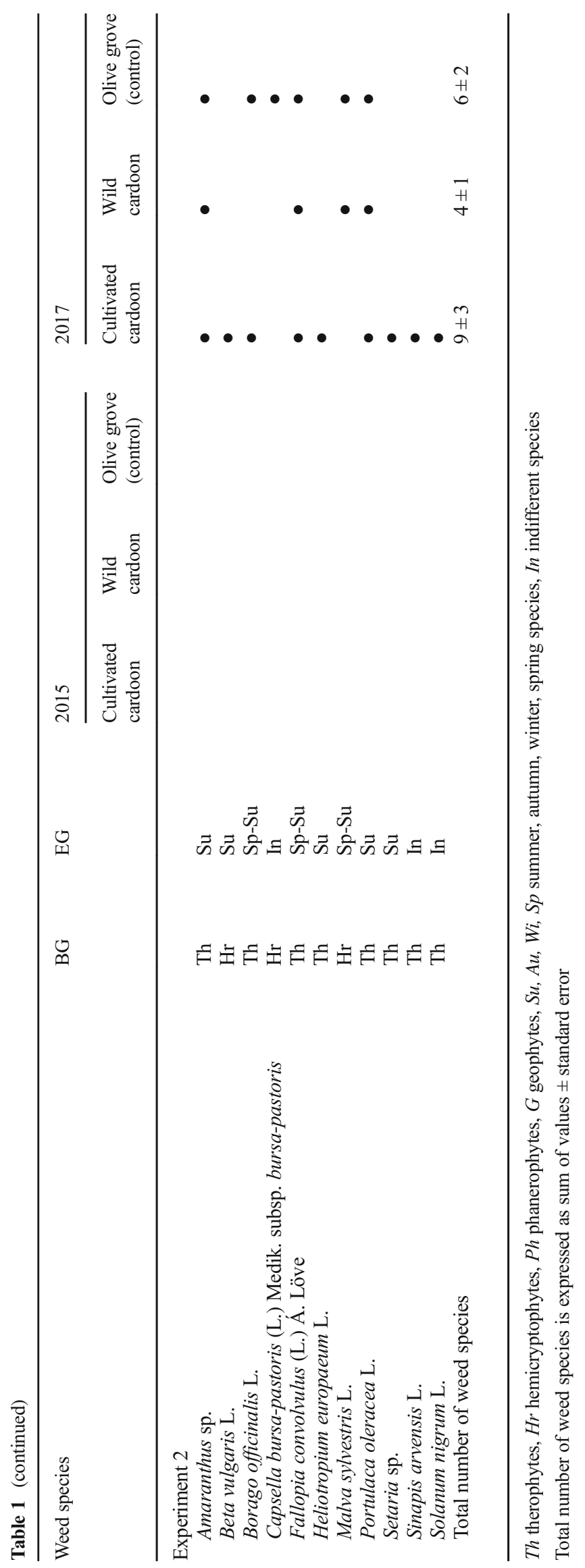


Helminthotheca echioides (L.) Holub (3000 seeds $\mathrm{m}^{-2}$ ) and Rumex spp. (3000 seeds $\mathrm{m}^{-2}$ ) in 2017. Moreover, in 2015, the cultivation of cardoon permitted the presence of seeds from only 7 weed species in the soil seed bank, with respect to the 12 of globe artichoke and the control (Table 1). However, the number of weed species in the seed bank increased in 2017, except for globe artichoke which allowed reducing to 8 species. Therefore, the permanence of globe artichoke for several years on the same field allows a reduction in the number of weed species. In experiment 2, 11 taxa belonging to nine botanical families were identified (Table 1). A high percentage of therophytes $(75 \%)$ was found as in the experiment 1 , followed by scapose hemicryptophytes $(17 \%)$ and biennial hemicryptophytes (8\%), while phanerophytes and geophytes were absent. On the total of weeds found, $90 \%$ were annual and $10 \%$ biennial. Amaranthus retroflexus L. was the most common weed in the soil seed bank (2622 seeds $\mathrm{m}^{-2}$ ), followed by Portulaca oleracea L. (733 seeds $\mathrm{m}^{-2}$ ). In cultivated soils, generally, the seed bank is represented by a small number of dominant weed species and a large amount of species in low numbers. According to Wilson (1988), the dominant species comprise from 70 to $90 \%$ of the total weed seed bank. The highest number of weed species was found in the cultivated cardoon plot (9), followed by the olive grove (6) (Table 1). The presence of wild cardoon for three consecutive years allowed the presence of only four weed species belonging to four botanical families, including Portulacaceae and Amaranthaceae, with P. oleracea and Amaranthus sp., respectively, representing about $90 \%$ of the seed bank. This aspect is of central importance for the weed management, since a lower number of species enables focusing on a specific control strategy.

Low qualitative and quantitative indices of similarity were determined between control and treatments both in the same and different year (Table 2). It proves that the composition of the soil seed bank changes both qualitatively and quantitatively in the globe artichoke and cultivated cardoon plots, compared to the wheat/fava bean rotation. The smallest qualitative index was ascertained between the plot with cultivated cardoon in 2017 and the control in 2015 (0.18), while the highest between both globe artichoke and cultivated cardoon in $2015(0.63)$. Quantitative index reached the lowest values between both cultivated cardoon and the control in 2017 (0.08), and between the control in 2015 and cultivated cardoon in 2017 (0.09).

Crop rotation is an important tool to lower weed pressure. Nevertheless, its contribution in agroecosystems is limited if done alone, becoming more effective when combined with other methods within an Integrated Weed Management Systems (Garrison et al. 2014). Given the results described above in monoculture, it is possible that $C$. cardunculus could also decrease the size of the soil weed seed bank in rotation, suggesting the possibility to introduce cultivated cardoon or globe artichoke within a crop rotation for 2-3 years. Other evidences are reported on the changes caused in weed populations by crop rotation, even after 2 years of crop sequences (Dorado et al. 1999; Bellinder et al. 2004). Many factors affect the quantity and quality of the weed seed bank under field conditions. However, considering the similarities between the plots in terms of climatic conditions, soil characteristics, and agronomic practices, it is reasonable to assert that the differences in the amount of weed seeds in the soil seed bank are related to the effects of globe artichoke and cultivated cardoon on the real and potential flora. These effects could be explained by two mechanisms: competition and allelopathy. C. cardunculus is an invasive perennial forb that, thanks to its high biomass production and well-developed root system, strongly competes with weeds for light, water, and nutrient uptake (White and Holt 2005), thus reducing the inputs of weed seeds into the soil seed bank. Furthermore, it can release allelochemicals into the rhizosphere through leaching from plant foliage, decomposition of plant residues on soil surface, and exudation from roots. The first two pathways of release appear to play a more important role, since the polyphenol and sesquiterpene content is higher in the aboveground parts of the plant, particularly in the leaves (Pandino et al. 2012). These

Table 2 Sørensen's qualitative and quantitative indices of similarity compared between all treatment combinations in experiment 1

\begin{tabular}{|c|c|c|c|c|c|c|c|}
\hline \multirow[t]{3}{*}{ Year } & \multirow[t]{3}{*}{ Crop } & \multicolumn{6}{|l|}{ Qualitative index } \\
\hline & & \multicolumn{3}{|l|}{2015} & \multicolumn{3}{|l|}{2017} \\
\hline & & Cultivated cardoon & Globe artichoke & $\begin{array}{l}\text { Faba bean } \\
\text { /wheat (control) }\end{array}$ & $\begin{array}{l}\text { Cultivated } \\
\text { cardoon }\end{array}$ & $\begin{array}{l}\text { Globe } \\
\text { artichoke }\end{array}$ & $\begin{array}{l}\text { Faba bean/wheat } \\
\text { (control) }\end{array}$ \\
\hline \multirow[t]{3}{*}{2015} & Cultivated cardoon & & 0.67 & 0.37 & 0.67 & 0.12 & 0.19 \\
\hline & Globe artichoke & 0.63 & & 0.25 & 0.47 & 0.32 & 0.12 \\
\hline & Faba bean/wheat (control) & 0.32 & 0.58 & & 0.09 & 0.07 & 0.72 \\
\hline \multirow[t]{4}{*}{2017} & Cultivated cardoon & 0.47 & 0.55 & 0.18 & & 0.19 & 0.08 \\
\hline & Globe artichoke & 0.27 & 0.40 & 0.30 & 0.44 & & 0.11 \\
\hline & Faba bean/wheat (control) & 0.31 & 0.33 & 0.22 & 0.38 & 0.29 & \\
\hline & & Quantitative index & & & & & \\
\hline
\end{tabular}


allelochemicals seem to exert an inhibitory effect on the weed population by preventing their flowering and seed germination. However, in field conditions, it is difficult to separate allelopathy from competition: stress caused by competition increase the production of allelochemicals, while growth reduction caused by allelochemicals may reduce the competitive ability of the inhibited plant (Scavo et al. 2018a). These mechanisms are also involved in the invasive behaviour of wild cardoon in California grasslands (Marushia and Holt 2006). Once released into the rhizosphere, allelochemicals enter in a complex plant-soil system in which different factors, both biotic and abiotic, affect their availability and, consequently, their effectiveness (Kruse et al. 2000). In order to manifest phytotoxic activity, allelochemicals should accumulate, persist at phytotoxic levels, and come in contact with target plants (Inderjit 2001). Furthermore, soil microorganisms significantly affect allelochemicals efficacy by converting them into more active, less active or entirely inactive compounds (Cipollini et al. 2012). Harper and Lynch (1982) suggested that the total allelopathic potential of plant residues is the result of watersoluble allelochemicals released by residues prior to decomposition, as well as the insoluble allelochemicals released by microorganisms during decomposition.

\subsection{Allelopathic effect on soil microbial community}

Figure 3 reports the DGGE results of soil eubacterial communities. Patterns proved to be very similar in terms of number and intensity of bands. However, the profiles showed the disappearance of some band and an intensification of others. In particular, the bands present in the soil control samples and indicated by the black box, became fainter in soil samples

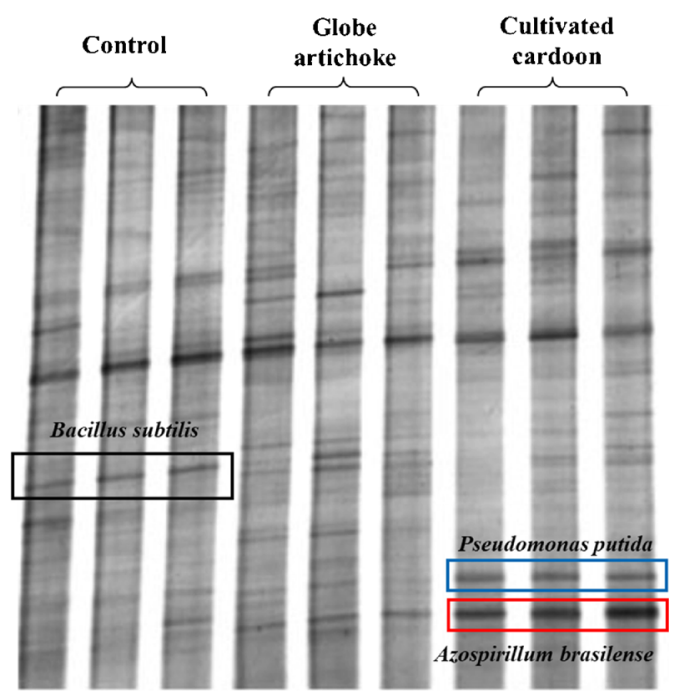

Fig. 3 Denaturing gradient gel electrophoresis (DGGE) patterns of $16 \mathrm{~S}$ rDNA fragments amplified from soil samples in experiment 1 . The molecular analyses were carried out in triplicate. Control: wheat/faba bean rotation cultivated with globe artichoke, until becoming very faint and perhaps disappearing in the presence of cultivated cardoon. At the same time, the gel showed that the presence of cultivated cardoon had a stimulating effect towards two microorganisms of the bacterial community. The microorganisms were identified by Biodiversity s.r.l., Brescia, Italy, using NCBI library, as B. subtilis (97\%), Pseudomonas putida (98\%), and Azospirillum brasilense (95\%), respectively.

The permanence of cultivated cardoon for three consecutive years showed both toxic and stimulatory effects on soil microorganisms. In fact, on one side it had a negative influence towards $B$. subtilis, while on the other, a positive one towards the beneficial soil bacteria $P$. putida and A. brasilense. B. subtilisis, which is non-toxic to humans, widely exists in soils and can produce a wealth of antibacterial substances including lipopeptides, polypeptides and phospholipids. It is a rod-shaped Gram-positive soil bacterium that produces endospores allowing survival in extreme environmental conditions, including heat and desiccation (Härtig and Jahn 2012). P. putida is a rod-shaped, flagellated, Gramnegative bacterium which is found in most of terrestrial and aquatic habitats in the presence of oxygen. Its optimum is between 25 and $30{ }^{\circ} \mathrm{C}$ and can be easily isolated. P. putida presents several strains such as the KT244, and it is considered a potential root colonizer for the rhizoremediation of pollutants and the biological control of pests. The peculiarity of this bacterium is due to the involvement of the most of its genes in the decomposition of aromatic or aliphatic hydrocarbons, which are dangerous chemicals caused by burning fuel, coal, tobacco, and other organic substances (Espinosa-Urgel et al. 2000). Azospirillum spp. are soil bacteria able to promote the growth of 113 plant species belonging to 35 botanical families. These non-pathogenic and beneficial bacteria are ubiquitous in soils and colonize the roots of several plants. Moreover, Azospirillum spp. are microaerophilic bacteria able to fix nitrogen under free-living conditions and to navigate in chemical gradients, including oxygen (Alexandre 2017).

The inhibition of $B$. subtilis by cultivated cardoon is probably caused by the secondary metabolites released into the rhizosphere. This is in accordance with Souto et al. (2001), who studying the allelopathic effects of tree species on some soil microbial populations and herbaceous plants, found that the proteolytic microorganisms such as Bacillus spp. were negatively affected by Eucalyptus globulus Labill. and Pinus radiata D.Don. On the other hand, the positive effects of cultivated cardoon on P. putida and A. brasilense suggest how these microorganisms can use the secondary metabolites released by the plant for their growth and metabolism, preventing the accumulation into the rhizosphere.

Allelopathy not only involves the direct effects of allelochemicals on target microorganisms, but also the indirect or functional allelopathy (Scavo et al. 2018a). In fact, when allelochemicals are released into the soil, they can be degraded 
or transformed by soil microorganisms, induce a third species to produce another compound which interferes with donor plants and/or cause changes on soil abiotic factors (Cipollini et al. 2012). Many different kinds and species of microorganisms populate the rhizosphere interacting with plants through root exudates. Nevertheless, each plant species cultivates a specific microbial rhizosphere community. Moreover, a twoway relationship exists between plants and microorganisms. Soil physical and chemical characteristics are other factors determining the kind of interaction, demonstrating the complexity of the process (Inderjit 2001).

The results outlined above show how the repeated cultivation for three consecutive years of $C$. cardunculus reduces the size of the soil seed bank by varying patterns of resource competition and allelopathic interactions. However, some of the most important negative effects associated with the maintenance of a single crop for several years on the same field are the reduction of nutrient availability, particularly that of nitrogen, and the imbalances in the soil microbial community. Our results on the in vitro antimicrobial activity of leaf extracts, with a similar trend to those reported by DGGE, highlight that cultivated cardoon does not exert negative effects on $R$. leguminosarum and S. meliloti, which are two important bacteria involved in BNF. In fact, only the Gram-positive bacterium $B$. licheniformis, except for WE, was negatively influenced by $\mathrm{ME}$ and $\mathrm{EE}$ at all concentrations tested. In particular, the ME showed a higher inhibitory activity (with inhibition haloes values of $23.5,22$, and $16 \mathrm{~mm}$ at $1.7676,1.473$, and $0.7365 \mathrm{mg}$ total polyphenols $\mathrm{mL}^{-1}$, respectively) with respect to $\mathrm{EE}(17.7,18$, and $21 \mathrm{~mm}$ at $1.2684,1.057$, and $0.5285 \mathrm{mg}$ total polyphenols $\mathrm{mL}^{-1}$, respectively). The other two Gramnegative bacteria did not show any inhibitory effect. The higher resistance of Gram-negative bacteria to antibiotics and other chemicals with respect to Gram-positive ones is explained by the presence of a double membrane surrounding each bacterial cell. In fact, although all bacteria have an inner cell membrane, Gram-negative bacteria have a unique outer membrane that excludes certain drugs and antibiotics from penetrating the cell.

\section{Conclusion}

In this study, the allelopathic activity of $C$. cardunculus in field conditions was studied for the first time in monoculture under a multidisciplinary approach. The presence of globe artichoke, cultivated and wild cardoon for three consecutive years significantly and markedly reduced the amount of weed seeds in the soil seed bank of two different areas. Nevertheless, cultivated cardoon had a negative influence towards $B$. subtilis, while positive effects were registered on P. putida and A. brasilense. Furthermore, cultivated cardoon leaf extracts did not exert in vitro negative effects on
R. leguminosarum and $S$. meliloti, while its methanolic and ethanolic extracts inhibited B. licheniformis at all concentrations tested. The microorganisms reported here are common in the soil, playing an important role in the decomposition, biodegradation and nitrogen cycle. In fact, they can use a wide range of carbon sources, including molecules such as xenobiotics, which few other organisms can break down. Therefore, C. cardunculus plays a positive role on the rhizosphere microbial community. Our promising results in monoculture would also be observed in a rotation system, suggesting the possibility of introducing the cultivated cardoon or the globe artichoke within a crop rotation in Mediterranean (or others) agroecosystems, especially under an Integrated Weed Management System, as an indirect method to reduce the weed soil seed bank pressure without adopting chemicalsynthesis herbicides and with respect for soil eubacterial communities. This eco-friendly weed management practice may be also employed in sustainable agriculture such as organic farming. Future perspectives for a better understanding of C. cardunculus field allelopathic activity involve the identification of its root exudates, the study on the persistence of its allelochemicals in the soil and the effects on the subsequent crop and microorganisms within a crop rotation.

\section{Compliance with ethical standards}

Conflict of interest The authors declare that they have no conflict of interest.

\section{References}

Alexandre G (2017) Azospirillum brasilense, a beneficial soil bacterium: isolation and cultivation. Curr Protoc Microbiol 47(1):3E.1.13E.1.10. https://doi.org/10.1002/cpmc.40

Alsaadawi IS, Sarbout AK, Al-Shamma LM (2012) Differential allelopathic potential of sunflower (Helianthus annuus L.) genotypes on weeds and wheat (Triticum aestivum L.) crop. Arch Agron Soil Sci 58(10):1139-1148. https://doi.org/10.1080/03650340.2011.570335

Bellinder RR, Dillard HR, Shah DA (2004) Weed seedbank community responses to crop rotation schemes. Crop Prot 23(2):95-101. https:// doi.org/10.1016/S0261-2194(03)00174-1

Cavers PB (1983) Seed demography. Can J Bot 61(12):3578-3590. https://doi.org/10.1139/b83-407

Chee-Sanford JC, Williams MM, Davis AS, Sims GK (2006) Do microorganisms influence seed-bank dynamics? Weed Sci 54(3):575587. https://doi.org/10.1614/WS-05-055R.1

Cipollini D, Rigsby CM, Barto EK (2012) Microbes as targets and mediators of allelopathy in plants. J Chem Ecol 38(6):714-727. https:// doi.org/10.1007/s10886-012-0133-7

Dorado J, Del Monte JP, Lopez-Fando C (1999) Weed seed bank response to crop rotation and tillage in semiarid agro-ecosystems. Weed Sci 47(1):67-73 www.jstor.org/stable/4046238

El Sohaimy SA (2014) Chemical composition, antioxidant and antimicrobial potential of artichoke. Open Nutraceuticals J 7:15-20. https://doi.org/10.2174/1876396001407010015

Espinosa-Urgel M, Salido A, Ramos JL (2000) Genetic analysis of functions involved in adhesion of Pseudomonas putida to seeds. J 
Bacteriol 182(9):2363-2369. https://doi.org/10.1128/JB.182.9. 2363-2369.2000

Farooq M, Jabran K, Cheema ZA, Wahid A, Siddique KHM (2011) The role of allelopathy in agricultural pest management. Pest Manag Sci 67(5):493-506. https://doi.org/10.1002/ps.2091

Felske A, Rheims H, Wolterink A, Stackebrandt E, Akkermans ADL (1997) Ribosome analysis reveals prominent activity of an uncultured member of the class Actinobacteria in grassland soils. Microbiol 143:2983-2989. https://doi.org/10.1099/00221287-1439-2983

Fenner M (2012) Seed ecology. Springer Science \& Business Media, Dordrecht. https://doi.org/10.1007/978-94-009-4844-0

Garrison AJ, Miller AD, Ryan MR, Roxburgh SH, Shea K (2014) Stacked crop rotations exploit weed-weed competition for sustainable weed management. Weed Sci 62(1):166-176. https://doi.org/ 10.1614/WS-D-13-00037.1

Harper SHT, Lynch JM (1982) The role of water-soluble components in phytotoxicity from decomposing straw. Plant Soil 65(1):11-17. https://doi.org/10.1007/BF02376798

Härtig E, Jahn D (2012) Chapter five - regulation of the anaerobic metabolism in Bacillus subtilis. Adv Microb Physiol 61:195-216. https://doi.org/10.1016/B978-0-12-394423-8.00005-6

Hossain MM, Begum M (2015) Soil weed seed bank: importance and management for sustainable crop production - a review. J Bangladesh Agric Univ 13(2):221-228. https://doi.org/10.3329/ jbau.v13i2.28783

Inderjit WJ (2001) Plant allelochemical interference or soil chemical ecology? Perspect Plant Ecol Evol Syst 4(1):3-12. https://doi.org/ 10.1078/1433-8319-00011

Kalburtji KL, Gagianas A (1997) Effects of sugar beet as a preceding crop on cotton. J Agron Crop Sci 178(1):59-63. https://doi.org/10.1111/j. 1439-037X.1997.tb00351.x

Kim JK, Park KJ, Cho KS, Nam SW, Park TJ, Bajpai R (2005) Aerobic nitrification-denitrification by heterotrophic Bacillus strains. Bioresour Technol 96(17):1897-1906. https://doi.org/10.1016/j. biortech.2005.01.040

Kruse M, Strandberg M, Strandberg B (2000) Ecological effects of allelopathic plants - a Review. NERI Technical Report No. 315, National Environmental Research Institute, Silkeborg, Denmark, 66

Kukić J, Popović V, Petrović S, Mucaji P, Ćirić A, Stojković D, Soković M (2008) Antioxidant and antimicrobial activity of Cynara cardunculus extracts. Food Chem 107(2):861-868. https://doi.org/ 10.1016/j.foodchem.2007.09.005

Magurran AE (2004) Measuring biological diversity. Blackwell Publishing, Oxford

Martin-Laurent F, Philippot L, Hallet S, Chaussod R, Germon JC, Soulas G, Cautroux G (2001) DNA extraction from soils: old bias for new microbial diversity analysis methods. Appl Environ Microbiol 67(5): 2354-2359. https://doi.org/10.1128/AEM.67.5.2354-2359.2001

Marushia RG, Holt JS (2006) The effects of habitat on dispersal patterns of an invasive thistle, Cynara cardunculus. Biol Invasions 8(4):577593. https://doi.org/10.1007/s10530-005-1601-6

Pagliaruolo C, De Vito V, Picariello G, Colicchio R, Pastore G, Salvatore P, Volpe MG (2016) Inhibitory effect of pomegranate (Punica granatum L.) polyphenol extracts on the bacterial growth and survival of clinical isolates of pathogenic Staphylococcus aureus and Escherichia coli. Food Chem 190:824-831. https://doi.org/10.1016/ j.foodchem.2015.06.028

Pandino G, Lombardo S, Williamson G, Mauromicale G (2012) Polyphenol profile and content in wild and cultivated Cynara cardunculus L. Ital J Agron 7(3):254-261. https://doi.org/10.4081/ ija.2012.e35

Peoples MB, Herridge DF, Ladha JK (1995) Biological nitrogen fixation: an efficient source of nitrogen for sustainable agriculture production? In: Ladha JK, Peoples MB (eds) Management of biological nitrogen fixation for the development of more productive and sustainable agricultural systems. Developments in plant and soil sciences. Springer, Dordrecht. https://doi.org/10.1007/978-94-0110055-7_1

Pesce GR, Negri M, Bacenetti J, Mauromicale G (2017) The biomethane, silage and biomass yield obtainable from three accessions of Cynara cardunculus. Ind Crop Prod 103:233-239. https://doi.org/10.1016/j. indcrop.2017.04.003

Portis E, Mauromicale G, Barchi L, Mauro R, Lanteri S (2005) Population structure and genetic variation in autochthonous globe artichoke germplasm from Sicily Island. Plant Sci 168(6):15911598. https://doi.org/10.1016/j.plantsci.2005.02.009

Scavo A, Restuccia A, Mauromicale G (2018a) Allelopathy: principles and basic aspects for agroecosystem control. In: Gaba S, Smith B, Lichtfouse E (eds) Sustainable Agriculture Reviews 28. Sustainable Agriculture Reviews, vol 28. Springer, Cham, pp 47-101

Scavo A, Restuccia A, Pandino G, Onofri A, Mauromicale G (2018b) Allelopathic effects of Cynara cardunculus L. leaf aqueous extracts on seed germination of some Mediterranean weed species. Ital $\mathrm{J}$ Agron 13(2):119-125. https://doi.org/10.4081/ija.2018.1021

Scavo A, Rial C, Molinillo JMG, Varela RM, Mauromicale G, Macías FA (2019a) The extraction procedure improves the allelopathic activity of cardoon (Cynara cardunculus var. altilis) leaf allelochemicals. Ind Crop Prod 128:479-487. https://doi.org/10.1016/j.indcrop. 2018.11.053

Scavo A, Pandino G, Restuccia C, Parafiti L, Cirvilleri G, Mauromicale G (2019b) Antimicrobial activity of cultivated cardoon (Cynara cardunculus L. var. altilis DC.) leaf extracts against bacterial species of agricultural and food interest. Ind Crop Prod 129:206-211. https://doi.org/10.1016/j.indcrop.2018.12.005

Singh BK, Millard P, Whiteley AS, Murrell JC (2004) Unravelling rhizosphere-microbial interactions: opportunities and limitations. Trends Microbiol 12(8):386-393. https://doi.org/10.1016/j.tim. 2004.06.008

Snapp SS, Swinton SM, Labarta R, Mutch D, Black JR, Leep R, Nyiraneza J, O'Neil K (2005) Evaluating cover crops for benefits, costs and performance within cropping system niches. Agron $\mathrm{J}$ 97(1):322-332. https://doi.org/10.2134/agronj2005.0322

Souto XC, Bolaño JC, González L, Reigosa MJ (2001) Allelopathic effects of tree species on some soil microbial populations and herbaceous plants. Biol Plant 44(2):269-275. https://doi.org/10.1023/ A: 1010259627812

White VA, Holt JS (2005) Competition of artichoke thistle (Cynara cardunculus) with native and exotic grassland species. Weed Sci 53(6):826-833. https://doi.org/10.1614/WS-04-171R.1

Wilson RG (1988) Biology of weed seeds in the soil) In: Altieri MA, Liebman M (eds) Weed management in agroecosystems. Ecological approaches. CRC Press, Boca Raton, FL, pp 25-39

Publisher's note Springer Nature remains neutral with regard to jurisdictional claims in published maps and institutional affiliations. 